technology. The decision on patent lifetime will not rest with WIPO, however, but with GATT (General Agreement on Tariffs and Trade), which will be considering harmonizing the term of patent protection in discussions of intellectual property rights next year.

Developing nations will be anxious for terms that recognize their special circumstances - the need to have access to sophisticated drugs at reasonable prices, for example. They intend to meet in Geneva before the June WIPO meeting in order to thrash out a common position on the treaty.

Christine McGourty

\section{AIDS \\ East Berlin risks grows}

\section{Munich}

TANGERINES and tape recorders are not all that East Germans are bringing back from their trips to West Berlin. Unless East German citizens take precautions, AIDS may be the next big import from the capitalist West. That is the view that emerged when East German public health official Niels Sönnichsen visited an AIDS self-help group in West Berlin.

Sönnichsen, who is at the East German Ministry of Health, and his counterparts in West Berlin have begun an information and condom distribution campaign. The campaign is unprecedented in East Germany, where AIDS was a taboo subject until just a few weeks ago. It is aimed at homosexual men, the only group currently at high risk for AIDS in East Germany. The main message: practise safe sex while in West Berlin.

With 16 confirmed cases of AIDS and seven deaths, East Germany has always been one of the most AIDS-free countries in Europe. By contrast, West Berlin, a city of about 2 million, has had 882 AIDS cases and 349 deaths, according to the West German Federal Health Office. The number of AIDS virus carriers in West Berlin is estimated to be between 5,000 and 10,000 . East Germany, with a population of more than $\mathbf{1 6}$ million, is thought to have 200 to 400 carriers.

But many of the West Berliners infected have been intravenous drug users, as many as $\mathbf{4 0}$ per cent of whom are thought to carry the virus. As there is virtually no drug trade in East Germany, only homosexuals are thought to be at risk there.

A self-help group, Berliner AIDS-Hilfe, has distributed condoms at homosexual meeting places in West Berlin since the wall was opened. The next step, said spokeswoman Birgit Thomas-Schön, is to give doctors in East Berlin training in diagnosis and counselling. But AIDS cannot be stopped at the border, says Meinrad Koch, head of the AIDS centre of the Federal Health Office in West Berlin.

Steven Dickman

\title{
Rescue mission prepared
}

\section{Washington}

THE mission of space shuttle Columbia, scheduled tentatively for launch on 8 January 1990 , will be the first occasion on which the shuttle performs a task that was originally intended to have been one of its routine activities - the return to Earth of a satellite put into orbit on a previous shuttle flight. If all goes well, the crew of Columbia will manoeuvre the shuttle next to a cylindrical canister known as the Long Duration Exposure Facility (LDEF), pull it into the cargo bay, and bring it back down to Earth, where scientists will see the outcome of 66 experiments that have been sitting in the cold and the dark for five and a half years.

LDEF, put into orbit in April 1984, is a 12 -sided cylinder, 30 feet long and 14 feet in diameter, holding 86 trays that contain a variety of simple experiments in physics, astronomy and biology. It was supposed to stay in low orbit for about a year, but before it could be retrieved, the Challenger explosion of January 1986 grounded the shuttle fleet for three years. This week's [planned] flight is an eleventh-hour mission: Columbia is the only shuttle with a cargo bay big enough to hold LDEF, and if the retrieval attempt fails, LDEF, now in a rapidly decaying orbit, will burn up in the Earth's atmosphere, probably by February next year.

The unexpected length of LDEF's flight, and the consequently aggravated effects of the upper atmosphere on its contents, could turn out to be the biggest problem for some of the experiments on board, according to Ernst Zinner, of Washington University in St Louis, Missouri, who is principal investigator of an experiment to capture interplanetary dust. Zinner's payload on LDEF consists of a number of 'sandwiches' of germanium plates in metallicized plastic foil coatings. Dust particles, travelling at speeds of 10 $\mathrm{km}$ per second, penetrate the foil but crash into the germanium and vaporize; the lower-speed fragments should then be retained by the foil coatings, so that the sandwiches retrieved from LDEF should harbour a five-year accumulation of deposited atoms whose isotopic composition will offer clues as to the origin of the dust. But Zinner is worried that some of his germanium sandwiches, placed in trays at the leading edge of the LDEF, will have been poisoned or damaged by the long exposure to atmospheric oxygen, in which case the germanium will contain an inseparable mix of terrestrial and extraterrestrial atoms.

But the unexpectedly long exposure of LDEF to the elements of space should also bring some rewards. Many of the experiments on board were designed to assess the damage suffered by a variety of materials on long exposure to dust, cosmic rays and meteorites, and the body of the LDEF canister itself will be examined closely for pitting and other ill-effects. This whole investigation will add greatly to the sparse body of knowledge on the durability of man-made structures in space, and should provide food for thought for the engineers now designing the space station.

One final LDEF experiment will give schoolchildren across the United States the chance to participate in a little space research. The George W. Park Seed Company of Greenwood, South Carolina, provided 12.5 million tomato seeds in packages loaded on to the LDEF for the Space Exposed Experiments Developed for Students (SEEDS), and set aside another 12.5 million which have been maintained in a sealed environment on the ground since April 1984. The tomato seeds will be divided up into kits of 50 exposed and 50 control seeds, and will be distributed to 250,000 schools as well as to some universities. Students are then free to investigate the effects of space exposure how they choose; young schoolchildren will be able to compare germination rates and times, while university students can look for genetic changes.

David Lindley

RESEARCH COUNCILS

\section{NERC on the up}

\section{London}

A "RESURGENCE" in the fortunes of the UK Natural Environment Research Council (NERC) after years of financial attrition, is the optimistic message of the council's report for the year ending 31 March 1989. At a press conference to publicize the report, NERC chairman Professor John Knill described how a 20 per cent rise in government funding over that for 1987-88 reflected "a dramatic change in public and political attitudes to environmental issues".

But the increase in resources available to NERC since the science budget announced in November 1988 did not prevent a 7 per cent cut in staff numbers over the year, a hangover from earlier financial problems. This year's science budget has yet to be allocated among the research councils.

The report also comments on proposals to reorganize the administration and funding of UK environmental research. NERC is opposed to a full merger with the Agriculture and Food Research Council (AFRC), first suggested by the House of Lords select committee on science and technology in October 1988. Nevertheless, there is "considerable logic in a partial merger between AFRC and NERC", perhaps within a division of a single National Research Council. Peter Aldhous 